\title{
STRESS, D -TYPE PERSONALITY AND CORONARY DISEASE
}

\author{
Jana Milic \\ University of Niš, Faculty of Philosophy, Nǐs, Serbia
}

\begin{abstract}
Stress is a non-specific state of a body caused by stressors. Stressor is a stimulus which, with its activity, produces a certain response which may be: physiological, emotional, cognitive and behavioural. The purpose of the research was to determine the connection and differences between personality traits (negative affectivity, social inhibition and psychosomatic inclination) of healthy people and patients with coronary disease, as well as their role in the development of the disease. The research was conducted on the sample of 43 respondents, with and without a coronary disease. It was found that there is a link between negative affectivity and social inhibition so that these two traits can be observable with part of the sample with a coronary disease. Dimensions of A type behaviour (achievement motivation), although it cannot be claimed for sure, have a significant role in the development of a coronary disease, that is, they are more noticeable. This was confirmed by our initial assumption, where this dimension is more dominant with women who have coronary problems.
\end{abstract}

Key words: A type behaviour, D type personality, coronary disease.

\section{Introduction}

This research is a small contribution to the understanding of the connection between personality and the development of a coronary disease. We gathered the literature about this problem so we could start to present it:

\section{Stress, stressor, concept and definition}

Stress is a non-specific state of body caused by stressors (an activity of physical and social surroundings). It can be constructive and pleasant, such that, as a rule, does not lead to the organic defects, in which case we speak about EUSTRESS. Stress like that is affection, a reward or success. The other type of stress causes morphofunctional disorganization and organic damages and is called DESTRESS [1].From the viewpoint of the Psychology of learning, stress (stimulus) affects body, $\mathrm{O}$ (organic, internal variable) would be changes inside the body caused by stressors, R (reaction) would be a reaction to stress. After a great many exposures to stress, a tendency to react stressfully is developed. The change of stressors, or the meaning of a stressor, would help the neutralization of a stimulus (stressor), the change of reaction to stress or the elimination of the stressful reaction. We react to a stimulus only when it has a meaning for us (neo, neobehaviorism) [2].

*Correspondence to: Jana Milić, PhD student Faculty of Philosophy, University of Niš, Ćirila i Metodija 2, 18000 Niš, Serbia Phone: +381 18514312

E-mail: jana.milic.psihologija@gmail.com

Received November $7^{\text {th }}, 2016$, accepted for publication January $16^{\text {th }}, 2017$

\section{Stressors and the division of stressors}

A stressor can be a stimulus of physical, social or psychological nature, which disturbs a healthy functioning of an individual [1].

1. Physical stressors: noise, vibration, physical exhaustion, magnetic effects, ionizing radiation, high and low temperature, humidity, weightlessness, electromagnetic radiation.

2. Chemical stressors: stressors of chemical nature which lead to poisoning.

3. Psychic stressors: loss of a loved one, divorce, moving house, job loss, wedding, pregnancy and childbirth, jail, retirement, financial problems, aging, change of weight due to aging.

\section{D type personality}

D type personality, called distressed type, is characterized by two traits, negative affectivity and social inhibition [1]. Negative affectivity is manifested by increased negative distress, and social inhibition represents a tendency towards inhibition and the expression of negative emotions in a social contact. D type persons are worried, of pessimistic perspective on the world, they are tense and unhappy. They are easily irritated and rarely have a positive attitude to life. They feel uncomfortable with unknown people and have few social connections [1]. They can be depressed, chronically tense, tired, exhausted. They have an increased activity of the sympathetic nervous system, the tendency to blood clotting and show signs of inflammatory processes [1]. Depression is most often associated with the variability of heart rate, increased heart irritability to psychological stress and higher ten- 
dency to blood clotting. D type personality has huge inclinations to developing cardiovascular disorders. There is no difference in systolic and diastolic blood pressure between the $\mathrm{D}$ type and other types, but $\mathrm{D}$ type heart problems are caused by psychic stress $[3,4]$.

\section{Coronary disease}

Myocardial heart attack - caused by thrombosis of lumen of one or more coronary blood vessels, which occurs on the ground of atherosclerotic plaques destabilization. This results in a necrosis of myocardium due to the reduction of myocardial blood flow [5,6].

Coronary vasospasm - antiplatelet therapy (aspirin, blockers of platelet receptors P2Y12) and calcium antagonist. Do not administer beta blockers since they provoke vasospasm [7]. Coronary vasospasm may have a significant role in the development of Atherosclerotic lesions [8].

Aortic stenosis - is a narrowing of an aortic valve, with a consequential obstruction which occurs during pumping out of blood from the left ventricle. It includes real stenosis, subvalvular and supravalvular stenosis [9].

\section{The heart as the organ of neurosis}

The conversion of symptoms into organs is characteristic of those people who retain their emotions in their bodies. Blushing, palpitations and shivering are reactions to specific eustress or distress emotions if we perceive an emotion as an $\mathrm{O}$ (organic) variable to a stimulus, and a stimulus can be an event. Arterial hypertension is characterized by a strong, instinctive tension which results from a strong tendency towards aggression as well as from a tendency to free oneself from that aggression. One appears calm on the outside, while not giving vent to one's impulses. Physiological research should provide some additional explanations for hormonal perturbations which cause arterial hypertension. We live in an aggressive world so this happens to people who believe or who have been taught that aggression is a bad thing [10]. Cytokines and other humoral mediators of inflammation activate the neurotransmitter systems which respond to stress. The sympathetic part of the autonomous nervous system is responsible for the regulation of the blood flow. Asthma, eczema and functional vascular diseases are caused by acute stress [11].

The goal of research was to establish the connection between type A behaviour and type D personality and coronary disease.

\section{Material and Methods}

\section{Sample}

The sample included 25 examinees with coronary disease (10 women and 15 men). There were 18 examinees without coronary problems (10 women and 8 men). Total sample included 43 examinees ( 20 women and 23 men). The examination took place in a room without noise in collabo- ration with a physician in the Life impulse clinic and in the coronary department of the General Hospital in Niš.

\section{The instruments}

The adaptation of Jenkin's Activity Scale for the evaluation of the type A behaviour consists of 12 supposed items of Likert's type and it is intended for the evaluation of the two components of behavioural style: the aspiration towards achievement and impatience irritability. The aspiration towards achievement relates to activity, ambition and the degree of how serious a person takes his/her job, whereas impatience - irritability involves intolerance, anger, hostility, as well as the preoccupation with the lack of time [12].

The scale for evaluation of the type $D$ personality consists of 14 items through which Negative affective attachment and Social inhibition are put into operation. Negative affectivity implies a stable tendency to experience sadness, depression, anxiety whereas social inhibition pertains to the inhibition in expressing the aforementioned emotions in social contacts. The responses can be placed on a five-level Likert's scale [13]. According to the test for measuring the efficiency of the system for the regulation and control of organic functions, HI from the bacterium KON-6, a tendency towards pshychosomatic mental disorders, is put into operation. HI regulator is formed through the joined action of subcortical centres for the regulation of the organic which are mostly placed within the region of the hypothalamus and their subordinate cortical centres for regulation and control. The disorder of this regulator causes the disorder of the basic systems of organs: cardiovascular, respiratory, gastrointestinal and urogenital as well as the functional disorders of the sensor and motor systems and the secondary creation of the hypochondriac reaction system in reaction to these basic organic functions [14].

\section{Results}

Table 1 presents mean values, standard deviation and standard errors of D-type and A-type behaviour, dimensional values of examinees with coronary disease and healthy examinees. Table 2 shows mean values, standard deviation and standard error means of dimensional values of D-type personality for male and female examinees, separately for those with and without coronary artery disease.

$\mathrm{HO}$ - There is statistically significant difference in dimensional values of D-type personality and A-type behavior between examinees with coronary disease and healthy examinees, regardless of their gender.

Statistically significant difference of aspiration for achievement, an A-type behavior characteristic, is more pronounced in diseased $(\mathrm{t}=-2.682, \mathrm{p}=0.10)$ examinees. A-type behavior characteristics are more pronounced in diseased examinees. There is no statistically significant difference of D-type characteristics for the sample group. 
It can be assumed that responsibility regarding life and profession is higher for diseased examinees.

This hypothesis is partially confirmed. Further hypotheses are made to determine the extent of characteristics for healthy and diseased examinees with respect to gender.

$\mathrm{H} 1$ - There is statistically significant difference of Dtype personality between male examinees with coronary disease and healthy male examinees. Statistically higher dimensional values are found $\mathrm{n}$ negative affection dimensional values of D-type personality among diseased male examinees than on the same values for healthy male examinees $(t=2.748, p<0.05)$. Hypothesis is confirmed.

It is assumed that dimension values of D-type, for the whole sample group, are more pronounced in diseased male examinees, regardless that this is not confirmed by H0. Diseased males make social contacts harder than healthy males and have stronger unpleasant emotions.
$\mathrm{H} 2$ - There is statistically significant difference of Atype behavior between male examinees with coronary disease and healthy male examinees. No statistically significant differences were found on dimensional values of A-type behavior between diseased male examinees and healthy male examinees. Higher statistically significant values in tendency towards psychosomatics are found in diseased male examinees than in healthy male examinees $(\mathrm{t}$ $=2.284, \mathrm{p}<0.05)$. This hypothesis is rejected. H0 had shown statistically significant difference in a dimension of A-type. Diseased males have more difficulties with conflicts and have tendencies towards physiological reactions when under stress.

H3 - There is statistically significant difference of D-type personality between female examinees with coronary disease and healthy female examinees. No statistically significant differences were found on

Table 1 Mean values, standard deviation and standard errors of D-type and A-type behaviour dimensional values of examinees with coronary disease and healthy examinees

\begin{tabular}{lccccc}
\hline & Coronary problems & $\mathrm{N}$ & Mean & Std. Deviation & Std. Error Mean \\
\hline \multirow{2}{*}{ Negative feelings } & Yes & 25 & 12.5200 & 6.50718 & 1.30144 \\
& No & 18 & 10.0556 & 8.05476 & 1.89852 \\
\hline \multirow{2}{*}{ Social inhibition } & Yes & 25 & 9.5200 & 4.62889 & 0.92578 \\
& No & 18 & 9.6111 & 4.96030 & 1.16915 \\
\hline \multirow{2}{*}{ Aspiration toward achievement } & Yes & 25 & 23.7200 & 5.48878 & 1.09776 \\
& No & 18 & 27.5556 & 3.01413 & 0.71044 \\
\hline \multirow{2}{*}{ Impatience-irritability } & Yes & 25 & 15.8800 & 3.50381 & 0.70076 \\
& No & 18 & 16.6667 & 6.24971 & 1.47307 \\
\hline
\end{tabular}

Table 2 Mean values, standard deviation and standard error means of dimensional values of D -type personality for male and female examinees

\begin{tabular}{lcrrrr}
\hline & $\begin{array}{c}\text { Coronary } \\
\text { problems }\end{array}$ & N & Mean & $\begin{array}{c}\text { Std. } \\
\text { Deviation }\end{array}$ & $\begin{array}{c}\text { Std. Error } \\
\text { Mean }\end{array}$ \\
\hline Males & & & & & \\
\hline \multirow{2}{*}{ Negative feelings } & Yes & 15 & 13.6667 & 8.08585 & 2.08776 \\
& No & 8 & 5.3750 & 3.42000 & 1.20915 \\
\hline \multirow{2}{*}{ Social inhibition } & Yes & 15 & 10.5333 & 4.65781 & 1.20264 \\
& No & 8 & 7.3750 & 4.80885 & 1.70018 \\
\hline \multirow{2}{*}{ Aspiration toward achievement } & Yes & 15 & 17.0000 & 3.85450 & .99523 \\
& No & 8 & 14.2500 & 6.60627 & 2.33567 \\
\hline \multirow{2}{*}{ Impatience-irritability } & Yes & 15 & 24.0667 & 5.56092 & 1.43582 \\
& No & 8 & 28.0000 & 2.92770 & 1.03510 \\
\hline \multirow{2}{*}{ Tendency towards psychosomatics } & Yes & 15 & 63.4000 & 24.85903 & 6.41857 \\
& No & 8 & 42.1250 & 11.05102 & 3.90712 \\
\hline Females & & & & & \\
\hline Negative feelings & Yes & 10 & 10.8000 & 2.39444 & 0.75719 \\
& No & 10 & 13.8000 & 8.85438 & 2.80000 \\
\hline Social inhibition & Yes & 10 & 8.0000 & 4.37163 & 1.38243 \\
& No & 10 & 11.4000 & 4.52647 & 1.43139 \\
\hline Aspiration toward achievement & Yes & 10 & 23.2000 & 5.63323 & 1.78139 \\
& No & 10 & 27.2000 & 3.19026 & 1.00885 \\
\hline Impatience-irritability & Yes & 10 & 14.2000 & 2.09762 & 0.66332 \\
& No & 10 & 18.6000 & 5.52167 & 1.74611 \\
\hline Tendency towards psychosomatics & Yes & 10 & 59.5000 & 12.96362 & 4.09946 \\
\hline & No & 10 & 64.9000 & 16.25115 & 5.13907 \\
\hline
\end{tabular}


dimensional values of D-type personality between diseased female examinees and healthy female examinees. This hypothesis is rejected.

$\mathrm{H} 4$ - There is statistically significant difference of Atype behavior between female examinees with coronary disease and healthy female examinees. Lower statistically significant values on impatience-irritability characteristic of A-type behavior are found in diseased female examinees than in healthy female examinees $(t=2.356, p$ $<0.05)$. This hypothesis is confirmed. Sensitivity in certain life situations is more pronounced in diseased females.

H5 - There is statistically significant difference of Dtype personality dimensions between healthy male examinees and healthy female examinees. No statistically significant values have been found. This hypothesis is rejected.

H6 - There is statistically significant difference of Atype behavior dimensions between male examinees and female examinees who suffer from coronary disease. No statistically significant values have been found. $\mathrm{H} 0$ could point out for a statistically significant difference of Atype dimensions for diseased and healthy females, as is confirmed by $\mathrm{H} 3$.

H7 - There is statistically significant difference of Atype behavior dimensions between healthy male examinees and healthy female examinees. No statistically significant values have been found. This hypothesis is rejected.

$\mathrm{H} 8$ - There is statistically significant difference of Atype behavior dimensions between male examinees and female examinees who suffer from coronary disease. Lower statistical significance values are found on impatience-irritability of A-type behavior characteristics for female examinees suffering from coronary disease than for male examinees suffering from coronary disease $(\mathrm{t}=-2.090, \mathrm{p}<0.05)$.

This hypothesis is confirmed.

H9 - There is statistically significant correlation of Atype and D-type characteristics for a whole sample group. Both D-type personality dimensions correlate with impatience-irritability of A-type behavior dimension. There is a higher correlation with negative affectivity (rho $=0.534, \mathrm{p}<0.001$ ) than with social inhibition (rho $=$ $0.379, p<0.05$ ). Two dimensions of D-type personality correlate significantly between each other $(\mathrm{rho}=0.568, \mathrm{p}$ $<0.001)$.

H10 - There is statistically significant correlation of A-type and D-type characteristics for healthy examinees. There is statistically significant correlation between negative affectivity and social inhibition, both dimensions of D-type personality (rho $=0.775, \mathrm{p}<0.001$ ). There is statistically significant correlation between impatienceirritability, characteristic of A-type behavior, and negative affectivity, characteristic of D-type personality (rho $=0.714, p=0.001)$. Unpleasant emotions can often be caused by our attitude towards life and situations we are in.

H11 - There is statistically significant correlation of A-type and D-type characteristics for examinees with coronary disease. There is statistically significant correlation between negative affectivity and social inhibition, both dimensions of D-type personality (rho = $0.396, \mathrm{p}<0.05)$.

H12- There is statistically significant correlation of Atype and D-type characteristics and tendency towards psychosomatics for the whole sample. Statistically significant correlation between tendency towards psychosomatics, negative affectivity (rho $=0.745, \mathrm{p}<0.001$ ) and social inhibition (rho $=0.424, \mathrm{p}=0.005$ ) (characteristics of D-type personality) and impatience-irritability (rho $=0.381, p<0.05)$ (characteristic of A-type behavior) is found. Physiological reactions to stress can often be provoked by psychological and social components.

H13 - There is statistically significant correlation between A-type and D-type characteristics and tendency towards psychosomatics for healthy examinees. Statistically significant correlation between tendency towards psychosomatics, negative affectivity (rho $=0.843$, $\mathrm{p}<0.001$ ) and social inhibition (rho $=0.650, \mathrm{p}<0.01$ ) (characteristics of D-type personality) and impatienceirritability (rho $=0.732, \mathrm{p}=0.001$ ) (characteristic of Atype behavior) is found. Physiological state of the organism is very much conditioned by psychological and social life components. Our attitudes, optimism, pessimism, falling back, fight, communication, conflict could determinate physiological basis of psychic life.

H14 - There is statistically significant correlation between A-type and D-type characteristics and tendency towards psychosomatics for healthy examinees. Correlation between tendency towards psychosomatics and negative affectivity (rho $=0.676, \mathrm{p}<0.001$ ) for diseased examinees is found. Physiological response to unpleasant emotions is in correlation.

\section{Discussion}

Our results showed that examinees with type A personality had more prominent tendency to coronary disease. This finding is interesting since this work was about type D personality and coronary disease. Aspiration for achievement (motives for success) was dominant in results and this motive is a part of type A personality. We cannot generalise to include the entire population with these results but we can say that some type A characteristics are correlated with coronary disease.

We found similar results with Danollet et al., that D type of personality was not the important cause for coronary disease $[13,15]$. It was not found in these researches that blood pressure was in correlation with D type personality. Therefore, someone who has blood pressure does not necessarily have a $\mathrm{D}$ type personality. According to Spence et al., A type of personality has a tendency towards a coronary disease due to more prominent motives for success and self-actualisation. People with this type of personality think about life and job very seriously. D type personality has problems in social relationships [1]. 
Individuals with Type A personality are hard-driving, competitive, aggressive and hurried. Type A behaviour is a risk factor for the development of coronary heart disease (CHD). However, there have been conflicting results in the literature primarily because of differences in methods and measurements of Type A behaviour. As a result, researchers have focused on subcomponents of the Type A behaviour pattern, particularly hostility and anger, which are more reliable predictors of CHD [16].

Type D personality was proposed by the psychologist Denollet in 1996 and was originally identified after observations of patients with CHD [17]. Type D personality is characterized by two personality traits: negative affectivity and social inhibition [13]. The synergistic effect of negative affectivity and social inhibition involves a higher risk of several emotional and social difficulties, such as depression, anxiety, a low level of subjective well-being, lack of social support and low quality of life [18]. Type D personality was based on the knowledge that psychosocial factors are associated with cardiovascular outcomes [19], and negative emotions and social inhibitions have been given special attention [20]. Type D personality has been associated with a variety of emotional and social difficulties, as well as increased morbidity and mortality in patients with established cardiovascular disease (CVD) [21]. Type D personality substantially affects the way in which patients with myocardial infarction (MI) perceive the availability of social support from different sources, including family, friends and others. Type D personality also plays a clinically relevant role in psychological health outcomes, as Type D patients report significantly higher levels of anxiety, depressive mood, perceived psychophysical stress, interpersonal difficulties, social anxiety and diminished psychophysical well-being and quality of life [22].

Type D personality had its origin in the cardiovascular context. In 1996, Denollet et al. proposed that Type D personality was an independent predictor of long-term mortality in patients with CHD, independently of traditional biomedical factors [17]. A subsequent study demonstrated that Type D personality patients with CHD had a fourfold increased risk of major cardiac events over 5 years, independent of disease severity [23]. Another study found that Type D personality predicted mortality and recurrent MI in patients with acute MI after controlling for both disease and depression severity [24]. Type D personality has also been studied regarding the risk of CHD in populations without clinically established CHD [25]. Findings across studies are inconsistent, as several studies have failed to find any associations between Type D personality and cardiovascular outcomes [26], and provided ambiguous evidence regarding whether Type D personality can predict CHD. Denollet et al. made the assumption that Type D personality is a significant predictor of cardiovascular events after adjustment for depressive symptoms because of the fact that the subcomponents of Type D personality, negative affectivity and social inhibition, activate different brain parts and result in different cortisol responses after exposure to social threats [27]. Research on the relationship between Type $\mathrm{D}$ personality and laboratory indices of cardiovascular health indicates that socially inhibited men have heightened blood pressure reactivity and that negative affectivity is related to a dampened heart-rate change during stress. Both Type D dimensions (negative affectivity and social inhibition) were associated with greater cortisol reactivity to stress [28,29]. Williams et al. compared males with and without Type D personality and found that the former group exhibited a significantly higher cardiac output during a stress condition. However, there was no relationship between Type D personality and cardiovascular reactivity in females [30]. It has been reported that $13-24 \%$ of individuals in a healthy adult population can be classified as a Type D personality. Kupper et al. found that the prevalence of Type D personality was higher among women. Moreover, females had significantly higher negative affectivity scores than males but males and females did not differ in their mean social inhibition scores. Age was not a significant covariate for either negative affectivity or social inhibition [31].

Further longitudinal studies are needed to clarify whether Type D personality and its traits remain stable over time and after life-changing events. Moreover, the influence, through disease promoting mechanisms, of Type D personality on health status in later life needs to be investigated.

\section{Conclusion}

This research has shown that personality dimensions have a significant part in a development of coronary disease. Physiological basis of psychic life is reflected upon man's constant struggle to preserve his health by changing the way of observing the position he is in, whether it is about social or motivational (inner) sphere of man's life. Our attitudes toward situations we are in contribute to better physical health. Although conclusion like this is not the goal of this paper, its goal is pure research, it can be said that some branches of psychology have offered ways of overcoming stress. Behaviorism can talk about changes of cognitive scheme towards stressors, strategies of overcoming stress, and psychotherapy affecting the motivational sphere of social life can talk about ways of resolving inner conflicts, better and more tolerant self-knowledge, self-support and choices, selftrust, hope, ability to love and understand, needs and selfactualization. Body psychotherapy can offer body relief from sustained emotions. Goal and purpose are also very significant things in human life.

At the end, it can be concluded that personality dimensions take a large part in the development of coronary disease. Higher statistically significant difference is found on A-type behavior dimension, which means that tendency towards achievement is more pronounced in examinees with coronary problems than in the healthy ones. 


\section{References}

1. Nešić. M. Psihoneuroendokrinologija stresa. Medicinski Fakultet: Niš, 2005. (in Serbian)

2. Radonjić. S. Uvod u psihologiju. Zavod za udžbenike i naučna sredstva: Beograd,1999. (in Serbian)

3. Denollet J, Kupper N, Widdershoven J, Willem J. Type D personality is associeted with low cardiovascular reactivity to acut mental stress in heart failure patients. Int J Psychophysiol 2013; 90:44-49.

4. Perk J, De Backer G, Gohlke H, Graham I, Reiner Z, Verschuren WM, et al. European Association for Cardiovascular Prevention \& Rehabilitation (EACPR). European guidelines on cardiovascular disease prevention in clinical practice (version 2012) : the fifth joint task force of the European society of cardiology and other societies oncardiovascular disease prevention in clinical practice (constituted by representatives of nine societies and by invited experts). Int J Behav Med 2012; 19: 403-488.

5. Apostolović S, Stanojević, D. Spontana disekcija koronarnih arterija kao uzrok akutnog koronarnog sindroma. In: Infarkt miokarda koji nije uzrokovan aterotrombozom koronarne arterije. Fakultet medicinskih nauka Univerziteta u Kragujevcu, Kragujevac, 2015. pp. 111-114. (in Serbian)

6. Apostolović S. Infarkt miokarda koji nije uzrokovan aterotrombozom koronarne arterije. Fakultet medicinskih nauka Univerziteta u Kragujevcu, 2015. (in Serbian)

7. Tomašević M, Aleksić S. Miokardni most kao uzrok miokardne ishemije. In: Infarkt miokarda koji nije uzrokovan aterotrombozom koronarne arterije. Fakultet medicinskih nauka Univerziteta u Kragujevcu, Kragujevac, 2015. pp. 154-156. (in Serbian)

8. Šalinger-Martinović S, Apostolović S. Spazam koronarnih arterija kao uzrok akutnog infarkta miokarda. In: Infarkt miokarda koji nije uzrokovan aterotrombozom koronarne arterije. Fakultet medicinskih nauka Univerziteta u Kragujevcu, Kragujevac, 2015. pp. 87-90. (in Serbian)

9. Miloradović V, Srećković M. Akutni infarkt miokarda u hipertrofičnoj kardiomiopatiji i aortnoj stenozi. In: Infarkt miokarda koji nije uzrokovan aterotrombozom koronarne arterije. Fakultet medicinskih nauka Univerziteta u Kragujevcu, Kragujevac, 2015. pp. 203-205. (Serbian)

10. Fenichel O. The psychoanalytic theory of neurosis. London, 1946.

11. Nešić M. Integrativni pristup u istraživanju stresa. Zbornik radova, Nauka i savremeni Univerzitet, Niš, 2012. (in Serbian)

12. Spence JT, Helmreich RL, Pred RS. Impatience versus achievement strivings in type A pattern: Differential effects on student's health and academic achievement. J Appl Psychol 1987; 72:522-528.

13. Denollet J. DS14: Standard assessment of negative affectivity, social inhibition, and Type D personality. Psychosom Med 2005; 67:89-97.

14. Momirović K, Wolf A, Džamonja Z. KON 6: Kibernetička baterija konativnih testova. Centar za primenjenu psihologiju: Beograd, 1992. (in Serbian)

15. Nyklíček I, Vorselaars A, Denollet J. Type D personality and cadiovascular function in daily life of people without documented cardiovascular disease. Int J Physiol 2011; 80:139-142.

16. Friedman HS, Booth-Kewley S. Personality, type A behavior, and coronary heart disease: the role of emotional expression. $\mathbf{J}$ Pers Soc Psychol 1987; 53(4):783-792.
17. Denollet J, Sys SU, Stroobant N, Rombouts H, Gillebert TC, Brutsaert DL. Personality as independent predictor of long-term mortality in patients with coronary heart disease. Lancet 1996 347(8999):417-421.

18. Mols F. Denollet J. Type D personality among noncardiovascular patient populations: a systematic review. Gen Hosp Psychiatry 2010; 32(1):66-72

19. Kop WJ. Chronic and acute psychological risk factors for clinical manifestations of coronary artery disease. Psychosom Med 1999; 61(4):476-487.

20. Compare A, Mommersteeg PM, Faletra F, Grossi E, Pasotti E, Moccetti T, Auricchio A. Personality traits, cardiac risk factors, and their association with presence and severity of coronary artery plaque in people with no history of cardiovascular disease. J Cardiovasc Med (Hagerstown) 2014; 15(5):423-430.

21. Pedersen SS, Denollet J. Type D personality, cardiac events, and impaired quality of life: a review. Eur J Cardiovasc Prev Rehabil 2003; 10(4):241-248.

22. Sogaro E, Schinina F, Burgisser C, Orso F, Pallante R, Aloi T, et al. Type D personality impairs quality of life, coping and short-term psychological outcome in patients attending an outpatient intensive program of cardiac rehabilitation. Monaldi Arch Chest Dis 2010; 74(4):181-191.

23. Denollet J, Pedersen SS, Vrints CJ, Conraads VM. Usefulness of type D personality in predicting five-year cardiac events above and beyond concurrent symptoms of stress in patients with coronary heart disease. Am J Cardiol 2006; 97(7):970-973.

24. Martens EJ, Mols F, Burg MM, Denollet J. Type D personality predicts clinical events after myocardial infarction, above and beyond disease severity and depression. J Clin Psychiatry 2010; 71(6):778-783.

25. Hausteiner C, Klupsch D, Emeny R, Baumert J, Ladwig KH; KORA Investigators. Clustering of negative affectivity and social inhibition in the community: prevalence of type D personality as a cardiovascular risk marker. Psychosom Med 2010; 72(2):163-171.

26. Larson NC, Barger SD, Sydeman SJ. Type D personality is not associated with coronary heart disease risk in a North American sample of retirement-aged adults. Int J Behav Med 2013; 20(2): 277-285.

27. Williams L, O'Connor RC, Grubb NR, O'Carroll RE. Type D personality and three-month psychosocial outcomes among patients post-myocardial infarction. J Psychosom Res, 2012; 72(6): 422-426

28. Denollet J, Pedersen SS, Vrints CJ, Conraads VM. Predictive value of social inhibition and negative affectivity for cardiovascular events and mortality in patients with coronary artery disease: the type D personality construct. Psychosom Med 2013; 75(9):873-881

29. Williams L, O'Carroll RE, O'Connor RC. Type D personality and cardiac output in response to stress. Psychol Health 2009; 24(5):489-500.

30. Aquarius AE, Smolderen KG, Hamming JF, De Vries J, Vriens PW, Denollet J. Type D personality and mortality in periphera arterial disease: a pilot study. Arch Surg 2009; 144(8):728-733.

31. Kupper N, Denollet J, de Geus EJ, Boomsma DI, Willemsen G: Heritability of type-D personality. Psychosom Med 2007; 69(7):675-681. 